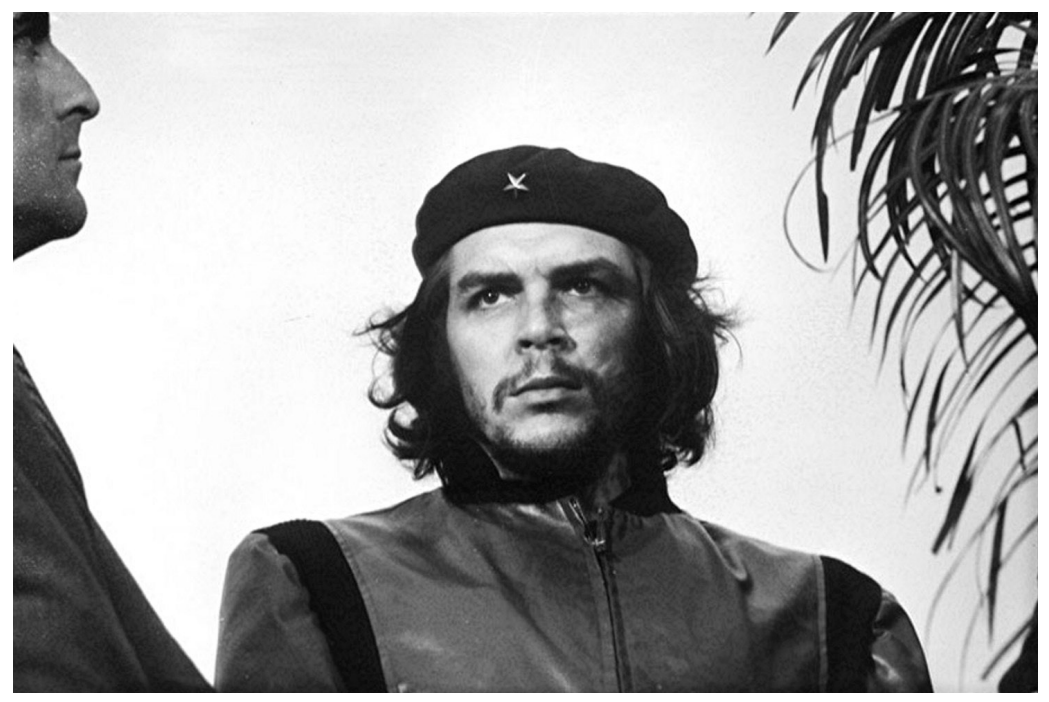

Guerrillero Heroico. Ernesto Che Guevara at the funeral for victims of the La Coubre explosion, I960. Photographer: Alberto Diaz Gutierrez (Alberto Korda). Public domain / Museo Che Guevara (Centro de Estudios Che Guevara en La Habana, Cuba). https://en.wikipedia.org/wiki/Guerrillero_ Heroico\#/media/File:Heroicor.jpg 


\section{The Soundtrack of Revolution: Memory, Affect, and the Power of Protest Songs}

\section{Overture}

We have all been there: Suddenly a melody comes into our heads without our knowing how it got there. On a recent trip to Cuba I heard the refrain of a long forgotten song: "Aquí se queda la clara / la entrañable transparencia / de tu querida presencia / Comandante Che Guevara" (Your beloved and luminous presence / became clear here / Comandante Che Guevara). With tears in my eyes I tried to explain to my partner that they were playing the song. "Which song?" she asked, but I was already heading for the bandstand, drawn by the music of Hasta Siempre (Forever), the popular song about Ernesto Guevara, better known to the world as Che or "Comandante."

It was my emotional and melodramatic soundtrack talking back to me. Many cultural representations in the form of songs, photographs, literature, theatre, film, television, and other media are so deeply ideologically engraved in our hearts that they are often difficult to define or analyze. Whether we like it or not, emotions are embedded as a cultural and social soundtrack of memories. Feminist scholarship over the past decade has emphasized that affects and emotions are the foundation of human interaction. The cognitive understanding of the world has given way to a gender analysis in which questions about the relationship between "our" and the "other's" feelings and how we relate to the world as human beings are central. ${ }^{\text {T }}$ The world is an affective place and life supplies us with melodies to accompany us on our journey.

What made me wonder was how the memory of a forgotten song transformed itself into a haunting melody? Hasta siempre is

How to cite this book chapter:

Rosenberg, Tiina 20I6. The Soundtrack of Revolution: Memory, Affect, and the Power of Protest Songs. In: Rosenberg, Tiina Don't Be Quiet, Start a Riot! Essays on Feminism and Performance. Pp. Ioo-I I6. Stockholm: Stockholm University Press. DOI: http://dx.doi.org/IO.I6993/baf.e. License: CC-BY 4.0 
performed everywhere in Cuba, but it was not the performance I recalled; it was the melody that persisted, clinging to me, and refusing to let go. It welcomed me and my memories back to Cuba.

\section{The haunting melody}

The interaction between melody and memory is complex. In The Haunting Melody, psychoanalyst Theodor Reik discusses his experiences in life and music. He asks what it means when a melody intrudes in the middle of unrelated thoughts, while your mind is occupied with rational and purposive considerations. ${ }^{2}$ Musical memory is linked to the process of retention, recall, and recognition, a notion that Sigmund Freud mentions in passing in his Psychopathology of Everyday Life but does not develop further. Freud's general aversion to music is his well-known, although late in life he developed a fondness for Mozart, especially Don Giovanni and Le nozze di Figaro. Brisk walks used to stimulate the flow of Freud's thoughts, rather than music. One of the reasons he disliked music has been identified as musicogenic epilepsy, a strong physical and memory-based epileptic reaction to music that Freud also observed in his patients. ${ }^{3}$ It is, of course, difficult to say why someone as culturally well-rounded as Freud was not found of music. He simply described himself as being "ganz unmusikalisch," totally unmusical. ${ }^{4}$

Other psychoanalysts have taken an interest in music, Reik among them. His curiosity in this area was awakened when a melody from Mahler's Symphony No. 2, The Resurrection, lodged in his mind during a walk in the Alps, an experience that he said took him a lifetime to understand. ${ }^{5}$ Reik describes how he was beset by Mahler's music, which refused to leave him. This experience made him want to write a book about melodies that haunt people. Reik hoped that an analysis of this phenomenon in general, and his own attraction to Mahler's symphony in particular, would help him understand the message of his unconscious. The outcome was a unique and fascinating self-analysis of what Reik heard in Mahler's music: it was the fundamental conflict that guided Reik's whole life, namely, the struggle between shameful feelings of worthlessness and grandiose overcompensation.

Reik discovered that melodies give voice to the unconscious: the unknown self begins to sing because music is so close to our 
emotions. He also found that the triumph of Mahler's symphony was not that it consoled him for the loss of a beloved friend, Karl Abraham; rather, it expressed his forbidden joy in Abraham's death. Reik had secretly longed to supplant Abraham in I925 as the world's leading psychoanalyst. He now concluded that the haunting melody that would not leave him was his unconscious trying to tell him something about his own self that had been forgotten or become constricted, something that was once important to him.

\section{Protests in public places}

It is midnight in Chicago's Grant Park on November 4, 2008. Barack Obama has just been elected the first African-American president of the United States. He stands on a platform in the chill night air and tells I००,००० cheering supporters, "It's been a long time coming, but tonight, because of what we did on this day, in this election, at this defining moment, change has come to America." "'The line has a familiar ring. It is a paraphrase of words written by soul singer Sam Cooke some forty-five years earlier: "It's been a long, a long time coming, but I know a change gon' come. ..” At this historic moment, the president-elect borrowed the most memorable line of his acceptance speech from an old protest song.

Most cities have a public space in the form of a central square. Recent demonstrations in the Middle East, at Syntagma Square in Athens, the Occupy Wall Street movement in the US, Los Indignados in Spain, and the student revolts in Chile are just a few examples of the return to the agora, Athens' classic square in which free citizens (women and slaves excluded) could participate in their city's democratic processes. Although today new social media are effective in spreading information, demonstrations still require the bodily presence of individuals in order to instill power into political slogans. There are many examples of the organization of public space in the history of demonstrations. The large trans-local Vietnam demonstrations of the late I960s, the demonstrations of the anti-globalization movement that began in Seattle in I999, the anti-war demonstrations over the invasion of Iraq in the early 2000 s, and the massive demonstrations in different parts of the world in 20I0 and 20II (so numerous and intense that 
Time magazine chose The Protester as the 20I I personality of the year) all showed how to occupy and use public space.

Public protests are a significant part of activist culture. The post 9/I I period has greatly restricted protests and the use of public space in the West. At the beginning of the twentieth century it was still possible to shut down factories, and sometimes even whole cities, through strikes. Protest occupations and sit-ins were a tool the labor movement used to challenge the capitalist political economy. Trade unions were linked in solidarity to form a larger social movement. "It created an awareness of the importance of 'taking' physical locations," observed historian Rosemary Feuer in an interview. ${ }^{7}$ New social media are important, but there is no revolt possible without a physical presence and the collective corporeality of specific locations. What remains of this tradition today, according to Feuer, are solidarity rallies that last for a day or two. She believes that the Arab Spring and its spin-off in the Occupy Wall Street movement have reminded people of the need to have physical social spaces in order to build protest movements and communities. ${ }^{8}$

\section{Protest songs}

Demonstrations, however, require more than physical locations in which to gather; the atmosphere is equally important. As a result, demonstration movements depend on certain vital aesthetic elements such as music. During the Arab Spring of $20 \mathrm{I}$ I, several songs were performed and recorded in Tahrir Square. The singer known as El General (Hamada Ben Amor) challenged the Tunisian president (now ex-president) Zine El Abedine Ben Ali with the song Mr. President, Your People are Dying, a protest refrain that quickly spread via the Internet. Hip-hop and rap have emerged as the genres of the younger generation's protest music because they are simply and cheaply produced, and because of their immediacy. In place of a band of musicians, all a rapper needs is a beat and something to say. It has become the undisputed contemporary genre for advancing social criticism. ${ }^{9}$

Protest and battle songs date back millennia. During the French Revolution people were marching to the tune of La Marsellaise, 
which was later to become the country's national anthem: "Aux armes, citoyens / formez vos bataillons / marchons, marchons! / Qu'un sang impur / Abreuve nos sillons!" (To arms, citizens / form your battalions! / March, march! / Let impure blood water our furrows!) The Internationale, the song of the labor movement that dates back to the early I9oos, is still sung on squares around the world on May Day in celebration of the movement's birth. In the I960s, the music of Bob Dylan and Joan Baez attracted thousands of people to outdoor concerts, while the London riots of 20I I were accompanied by dance music that created a completely different atmosphere, reminiscent of some of the sounds of The Clash's classic London Calling. ${ }^{\text {Io }}$

The commitment and mood of political gatherings are what drew people to such demonstrations. Baez, who rose to prominence at the Newport Festival in 1960, fought against racism with Martin Luther King Jr., traveled to Vietnam, and was imprisoned, has stated that "politics would be very unrealistic in the streets unless it involves music. The music pours forth from the soul, especially in times of crisis." "I She sees rock and pop music as having coincided in a fruitful union in the American protest movements of I960s and I970s: "I call it 'the perfect storm': the music, politics, the civil rights movement, the war in Vietnam." ${ }_{\text {I2 }}$ Dorian Lynskey writes that in order for a protest song to take hold it must be part of a larger political movement. He concludes that while the past fifteen years may have seen many protest songs, no larger social movement has emerged to unite them. However, music can act as a mediator and cohesive element, as has happened to the Internet-based music culture of the Arab Spring. ${ }^{\mathrm{I3}}$

Lynskey treats protest songs as a form of pop music that arises out of concern, anger, doubt, and, in almost every case, sincere emotion. However, film scholar Linda Williams points to melodrama, horror, and pornographic films as "body genres" that use tears, fear, and sexual arousal to elicit visceral reactions among viewers. ${ }^{14} \mathrm{Her}$ idea recalls Aristotle's theory of catharsis and can also be applied to a certain kind of music that requires immense exertion from performers and, in turn, provokes strong corporeal responses among members of the audience. Protest song is such a genre.

An emotion is usually the immediate physiological reaction to a 
stimulus. Characteristic of emotions is that they are bodily expressions, and bodily responses are more immediate than conscious emotional awareness. Human beings become aware of their reactions only after the fact. Affects are inscribed on our emotional and memory-based soundtracks early in life. These memories are archived and may appear when least expected. Bodily-based affects are the total sum of the events one has experienced. Thus, how people relate to their emotions is not only determined by the individual, but by one's life history and the culture of which we are all a part as well. My trip to Cuba brought something vital from the past to life again. In my own case it took the form of tears.

\section{The refrain of a song}

Hasta siempre exists in a number of versions: the Cuban revolutionary original, a rock tune, Latino pop, jazz, salsa, bolero, reggae, and hip-hop/rap. The Cuban composer Carlos Pueblo wrote it in 1965 in response to Che Guevara's farewell letter to the Cuban people. Hasta siempre expresses the gratitude of the Cuban people to their beloved Che.

Aprendimos a quererte / desde la histórica altura donde el sol de tu bravura / le puso cerco a la muerte. Chrous: Aquí se queda la clara / la entrañable transparencia / de tu querida presencia / Comandante Che Guevara. Tu mano gloriosa y fuerte /sobre la historia dispara / cuando todo Santa Clara / se despierta para verte. Chorus: Aquí se queda la clara / la entrañable transparencia / de tu querida presencia / Comandante Che Guevara. Vienes quemando la brisa / con soles de primavera/ para plantar la bandera / con la luz de tu sonrisa. Chorus: Aquí se queda la clara / la entrañable transparencia / de tu querida presencia / Comandante Che Guevara. Tu amor revolucionario / te conduce a nueva empresa / donde esperan la firmeza / de tu brazo libertario. Chrous: Aquí se queda la clara / la entrañable transparencia / de tu querida presencia / Comandante Che Guevara. Seguiremos adelante/ como junto a ti seguimos / y con Fidel te decimos: Hasta siempre, Comandante! Chrous: Aquí se queda la clara / la entrañable transparencia / de tu querida presencia / Comandante Che Guevara.

In English translation, the song goes something like this: 
We learned to love you / from the heights of history / with the radiance of your bravery / you laid siege to death. Chorus: Your beloved and luminous presence / became clear here / Comandante Che Guevara. Your glorious and strong hand / fires at history / when all of Santa Clara / awakens to see you. Chorus: Your beloved and luminous presence / became clear here / Comandante Che Guevara. You come burning the winds / with spring suns to plant the flag / with the light of your smile. Chorus: Your beloved and luminous presence / became clear here / Comandante Che Guevara. Your revolutionary love / leads you to a new undertaking / where they are awaiting the firmness/ of your liberating arm. Chorus: Your beloved and luminous presence / became clear here / Comandante Che Guevara. We will carry on / as we did together with you / and with Fidel we say to you / You will always be with us, Comandante! Chorus: Your beloved and luminous presence/ became clear here / Comandante Che Guevara.

Hasta siempre has clear religious overtones that it associates with a male revolutionary hero. It is not difficult to recognize the worship of another stereotypical altruistic male revolutionary, Jesus Christ, as the paradigm of Hasta siempre. It may, therefore, be relevant to ask whether I, as a queer feminist, can forgive anything for a good tune. Why am I crying as I listen to Hasta siempre, although I can understand all the problems connected with this sort of worship? I have elsewhere dealt with affect, voice, gender, and sexuality: the mezzo soprano in trouser roles ("the Sapphonics"); women in Wagner's operas (voice and power); Zarah Leander and queer diva culture; and, most recently, anger, hope, and solidarity. ${ }^{\mathrm{I5}}$ The emotional connections are complex and we are not always in control of how our internal soundboard resonates when played upon by certain melodies. In Reik's psychoanalytical terms it is the unknown or forgotten self that sings in our heads.

As described in earlier essays in Chapters I and 2, Roland Barthes proposes the rebirth of the author "inside" of the artwork. He eliminates a specifically male position (i.e., the author, logos) by supplanting it with its overtly female, musical force: the voice. What we experience, Barthes writes, is the voice, not the musical notation, and it transcends its "masculinity." "I In Barthes's thought, as in French poststructuralist theory in general, the 
feminine is a utopic space - the Promised Land we have not yet experienced. The voice is characterized by a certain instability that a prescriptive narrative has difficulty controlling. Thus, the person who gives voice to a haunting melody in a performance does not merely convey a given piece of music. She unlocks something forgotten that was once important to the listener, whose reaction need not be one of Freudian musicogenic epilepsy, although it is a physical occurrence nonetheless.

For Barthes, listening is a space where body and language meet, yet without completely merging into one another. ${ }^{17}$ In this combination of the abstract and the corporeal he sees an art form devoid of a system of signifier and signified. The grain of the voice is the materiality of the body speaking its mother tongue. In my own case Hasta siempre carried me back to my personal entrance into leftist politics. The military takeover by Augusto Pinochet in Chile in 1973 awakened me politically when I was fifteen years old. This early political engagement was accompanied by a musical repertory of protest songs that I have carried in my memory to this day. Hasta siempre, in Barthes's terms, was my memory speaking in its mother tongue.

\section{Sentimentality and revolutionary kitsch}

I understand, of course, that I am the perfect target for the Cuban tourist industry in branding revolutionary nostalgia as kitsch and selling it to middle-aged leftist visitors from the West. My tears over unfinished revolutions of all kinds are an illustration of political sentimentality (but also frustration) over the state of leftist politics today.

Sentimentality has gotten a bad reputation because of its tawdry aesthetics. The scholars and theorists who associate sentimentality with kitsch, especially those who do so with political aspirations, are not only attentive analysts of loving and tender feelings: they also position sentimentality in a broader cultural and political context. There is no consensus as to what constitutes kitsch, but ever since the term was coined in Germany around 1870 , it has enjoyed a certain notoriety as an epithet that denotes worthless, commercial art, or simply any kind of poor, 
mass-produced art with direct access to the emotions. ${ }^{18}$ Emotions have long been viewed with suspicion, although some philosophers such as Hume have praised the value of emotions in relation to reason, rationality, and morality. Research increasingly shows that emotions cannot only be seen as a threat to rationality, but may be a prerequisite to it. ${ }^{19}$ Theorists have emphasized how affects have assumed a central role in society, especially as elements of social networks and new social media.

Feminist theorist Sara Ahmed explores how emotions work to shape the "surfaces" of individual and collective bodies, so that bodies take the shape of the contact they have with objects and others. ${ }^{20}$

One way of reflecting on this history of thinking about emotion is to consider the debate about the relation between emotion, bodily sensation and cognition.

Emotion is the feeling of bodily change. The immediacy of the 'is' suggests that emotions do not involve processes of attribution or evaluation: we feel fear, for example, because our heart is racing, our skin is sweating. A cognitivist view would be represented by Aristotle, and by a number of thinkers who follow him. ${ }^{2 \mathrm{r}}$

Approaching emotions as a form of cultural politics or worldmaking, Ahmed finds that the cultural politics of emotions

developed not only as a critique of the psychologizing and privatization of emotions, but also as a critique of a model of social structure that neglects the emotional intensities, which allow such structures to be reified as forms of being. Attention to emotions allows us to address the question of how subjects become invested in particular structures such that their demise is felt as a kind of living death. ${ }^{22}$

The early critique of kitsch and sentimentality in the I950s and I960s was based on an analysis of Nazism and its use of emotionality for political propaganda. Queer theorists interested in camp as a special cultural sensibility have reevaluated this notion for queer culture. Susan Sontag was the first to do so in her groundbreaking essay "Notes on Camp," followed by a number of queer scholars writing on aesthetic theory. ${ }^{23}$ David Bergman has formulated a general definition of camp as follows: 
First, everyone agrees that camp is a style (whether of objects or of the way objects are perceived is debated) that favors 'exaggeration', 'artifice' and 'extremity'. Second, camp exists in tension with popular culture, commercial culture, or consumerist culture. Third, the person who can recognize camp, who sees things as campy, or who can camp is a person outside of the cultural mainstream. Fourth, camp is affiliated with homosexual culture, or at least with a self-conscious eroticism that throws into question the naturalization of desire. ${ }^{24}$

In this reinterpretation of kitsch as an element of camp, it forms its own aesthetic category, a status it shares with queer as culturally undesirable. Also, like queer, kitsch has been banished to the nether realms of cultural history, to oblivion, the domain of the invisible and inaudible. As stated in the previous chapter, much like the way sentimentality is denied or described as perverse, the disdain for kitsch appears to have created for itself a special place of cultural and artistic non-existence that constantly demands vigilance to keep contained, but at the same time has to be disregarded so as not to sully normative 'great' art and culture. Nevertheless, unsophisticated junk - artistic detritus - has a unique allure. ${ }^{25}$ There is a reason why Flaubert's Emma Bovary wallows in a sentimental flood of emotions. It is about pleasure, shameful and guilty as it may be, but still pleasurable in opposition to the dreariness of work and everyday routines. Richard Dyer writes that the dream of being at one with one's body and in harmony with other bodies (united in and through differences) is the feeling of socialism. However, socialism does not emanate from us naturally: it is the harmony we create together. ${ }^{26}$

\section{Last movement}

I enjoyed my revolutionary kitsch because it reminded me of many things I still believe in. ${ }^{27}$ While a great deal of music is compelling, kitschy sentimentalism seems to possess overwhelming power that circumvents common sense and goes straight for the emotions. As in the case of Zarah Leander in Chapter 4, revolutionary kitsch merges tears, body, and sensuality to form a unity that does not slacken its grip. 
The complex emotions Hasta siempre aroused in me after so many years are a tribute to the emotional power of music. Music as a mediator of the emotions is more potent than words because melody is closer to our feelings than logos. By the time a melody resurfaces and takes possession of our minds, we may wonder how it came there. The haunting Cuban melody also reminded me that one never gets the revolution one wants. Human life and social justice require solidarity, but solidarity cannot be their sole element. New social movements and their accompanying coalition politics often refuse to let themselves be guided by political parties or parliamentary systems. While they may make room for novel social forces that may emerge, they often fail to achieve a durable, comprehensive political solution without falling into totalitarianism.

If political empathy makes us share the feelings and experiences of others, solidarity, which affirms our humanity, becomes an attribute with principles. Empathy can foster individualization or a group-specific collectivization of emotion, but it may not necessarily extend to broader social issues. It is in the recognition of the other's needs that politics begin, a process that also plays a vital role in art.

Feminists cannot focus exclusively on gender, just as socialists cannot concern themselves only with class relations. Contemporary leftist movements that deal with commonalities do not require uniformity in their political ranks, but they must stress multi-solidarity. Being a member of the anti-racist struggle should make it easier to have a feminist perspective on racism, tie the fists against homophobia, and believe that a clear boundary will always exist between rich and poor. Multi-solidarity means that although a person may feel most at home in one social movement, other perspectives should not be rejected. Even Marxist theorist Antonio Gramsci realized that the Left needs to incorporate new social movements, regardless of their transient ideological status. ${ }^{28}$ The price for not doing so is reaction and ultimately fascism, as the dominant classes and their representatives come to fear that such movements may threaten their interests.

Multi-solidarity is inspiring, not divisive. It forces us to cooperate with one another across borders, but not at each other's expense. The decision to give priority to class struggle was used 
by the early labor movement as an argument against addressing women's demands for action. Not until the r970s did socialist feminists dare to question such a dichotomy and unite under a new slogan: "No class struggle without women's struggle, no women's struggle without class struggle." Multi-solidarity encourages parallel perspectives. One form of discrimination recognizes the other, and so both are addressed by a larger social movement where political questions are voiced and negotiated. Freedom requires interpersonal solidarity, ethical action, meaningful work, cultural awareness, and shared prosperity. People can only be free together, not in isolation.

The Cubans have had considerable success in developing a musical culture to accompany the Revolution. The iconic power of the Cuban Revolution has inspired the kind of solidarity and devotion that Wayne Koestenbaum has characterized in his works on Maria Callas and Jackie Kennedy. ${ }^{29}$ The worship of these two icons can be puzzling, but seems to release a yearning for a different kind of life among their devoted fans. Emotional experiences are amplified and have legitimacy when others share them, enabling the many to do things they could not have accomplished on their own. One way to bring this about is by rallying people around common symbols. Dyer points out that entertainment "presents, head-on as it were, what utopia would feel like, rather than how it would be organized. It thus works at the level of sensibility, by which I mean an affective code that is characteristic of, and largely specific to, a given mode of cultural production." ${ }^{30}$ In a word, Hasta siempre makes me feel the revolution.

There are certainly many important things I have forgotten over my life's course - memories that need to be acknowledged and reflected upon. These memories are no coincidences, Freud would say; they are my forgotten self singing to me. Embarrassing, perhaps. But Reik's recollection of two lines from a childhood song that came back to him while writing The Haunting Melody is comforting. It was a refrain that seemed to echo the final scene in Odysseus' wanderings when, with an oar on his shoulder, he sets forth once more from his cherished home to seek an abode of peace. His quest seems to mirror Reik's own thought: "Wo man singt, da lass dich ruhig nieder, böse Menschen haben keine 
Lieder" (Where people are singing, that's where you should settle down. Evil men don't have songs. $)^{31}$

\section{Notes}

I. Ahmed, Cultural Politics, 5-I 2.

2. Reik, Haunting Melody, vii.

3. Roth, "Freud's Dislike of Music."

4. Ibid., 759 .

5. Reik, Haunting Melody, 220.

6. Lynskey, Thirty-three Revolutions, xiii.

7. Quoted in Hellquist, Mästare i protester, 6.

8. Ibid.

9. Eyerman \& Jamison, Music and Social Movements; Hebdige, Subculture; Lynskey, Thirty-three Revolutions; Rose, Hip Hop Wars; Sernhede \& Söderman, Hip Hop in Sweden.

Io. Lynskey, Thirty-three Revolutions; xiii.

I I. Ibid.

I2. Quoted in Hellquist, Mästare i protester.

I3. Lynskey, Thirty-three Revolutions, xiii-xvi.

I4. Williams, Film Bodies.

I 5. Rosenberg, Byxbegär; "Touch of Opera"; "Elsa!"; Bögarnas Zarah; Ilska, hopp och solidaritet.

I6. Barthes, Le grain de las voix.

I7. Ibid.

I 8. Broch, "Einige Bemerkungen."

I9. Ahmed, Cultural Politics; Berlant, Compassion; Cvetkovich, Archive of Feelings; Nussbaum, Upheavals of Thought.

20. Ahmed, Cultural Politics, I.

2I. Ibid., 2.

22. Ibid., I 2 . 
23. Sontag, "Notes on 'Camp"”; Cleto, Camp; Dyer, "Entertainment and Utopia"; Koestenbaum, The Queen's Throat.

24. Quoted in Cleto, Camp, 4.

25. Rosenberg, Bögarnas Zarah.

26. Dyer, "A Bit of Uplift," I3.

27. Higgins, "Sweet Kitsch.”

28. Gramsci, Prison Notebooks.

29. Koestenbaum, The Queen's Throat; Jackie Under My Skin; Cleavage.

30. Dyer, "Entertainment and Utopia," 20.

3 I. Reik, Haunting Melody, I45

\section{Works Cited}

Ahmed, Sara. The Cultural Politics of Emotion. New York: Routledge, 2004 .

Barthes, Roland. Le grain de la voix: Entretiens 1962-1980, Paris: Editions de Seuil, I98 I.

Berlant, Lauren, ed. Compassion: The Culture and Politics of an Emotion. New York: Routledge, 2004.

Broch, Hermann. "Einige Bemerkungen zum Problem des Kitsches." In Dichten und Erkennen, Essays - Band I (Gesammelte Werke [6]), 295-309. Zurich: Rhein Verlag, I955.

Cleto, Fabio. Camp: Queer Aesthetics and the Performing Subject. A Reader. Ann Arbor: University of Michigan Press, I999.

Cvetkovich, Ann. An Archive of Feelings: Trauma, Sexuality, and Lesbian Public Cultures. Durham: Duke University Press, 2003.

Deutschmann, David, and Deborah Shnookal. Fidel Castro Reader. Melbourne: Ocean Press, 2007.

Dyer, Richard. "Entertainment and Utopia.” In Only Entertainment, I9-36. London: Routledge, 2002 [I992].

."A Bit of Uplift." In Only Entertainment, Iо-13. London: Routledge, 2002 [I992]. 
Eyerman, Ron, and Andrew Jamison. Music and Social Movements: Mobilizing Traditions in the Twentieth Century. Cambridge, UK: Cambridge University Press, I998.

Felski, Rita. The Gender of Modernity. Cambridge, MA: Harvard University Press, I995.

Giesz, Ludwig. Phänomenologie des Kitsches. Munich: Wilhelm Fink Verlag, I97I.

Gramsci, Antonio. Selections from the Prison Notebooks. London: Lawrence \& Wishart, I97I.

Hebdige, Dick. Subculture: The Meaning of Style. London: Methuen, I979.

Hellquist, Annie. "Mästare i protester" (Masters of Protests). Arbetaren 5I-52 (20II): 6.

Higgins, Kathleen. "Sweet Kitsch.” In The Philosophy of the Visual Arts, edited by Philip Alperson, 568-582. New York: Oxford University Press, I990.

Knight, Deborah. "Why We Enjoy Condemning Sentimentality: A Meta-Aesthetic Perspective." Journal of Aesthetics and Art Criticism 57 (I999): 4I I-420.

Koestenbaum, Wayne. The Queen's Throat: Opera, Homosexuality and the Mystery of Desire. London: Penguin, I993.

Penguin, I996.

- Cleavage: Essays on Sex, Stars, and Aesthetics. New York: Ballantine, 2000.

Kulka, Thomas. "Kitsch.” British Journal of Aesthetics 28 (I988): I 8-27.

Kupfer Joseph. "The Sentimental Self." Canadian Journal of Philosophy 20 (1996): 543-550.

Lynskey, Dorian. 33 Revolutions Per Minute: A History of Protest Songs from Billie Holiday to Green Day. London: Harper Collins, 2OII.

Nietzsche, Friedrich. Der Fall Wagner: Schriften und Aufzeichnungen über Richard Wagner. Frankfurt: Insel Verlag, I983 [I 888]. 
Nussbaum, Martha. Upheavals of Thought: The Intelligence of Emotions. Cambridge, UK: Cambridge University Press, 2003.

Reik, Theodor. The Haunting Melody: Psychoanalytic Experiences in Life and Music. New York: Farrar, I953.

Rose, Tricia. Black Noise: Rap Music and Black Culture in Contemporary America. Liverpool: Wesleyan University Press, I994.

. The Hip Hop Wars: What We Talk About When We Talk About Hip Hop and Why It Matters. New York: Basic Books, 2008.

Rosenberg, Tiina. "The Touch of Opera: Or, Can a Feminist Forgive Anything for a Good Tune?" Journal of Theatre and Drama 4 (I998): 23-36.

. Byxbegär (Desiring Pants). Gothenburg: Anamma, 2000.

. "Elsa! Har du väl förstått mig? Feministiska reflexioner kring Wagners Lohengrin ("Elsa! Do You Understand What I Am Saying? Feminist Reflections on Wagner's Lohengrin"). In Operavärldar, edited by Torsten Pettersson, I9I-2 I 8. Stockholm: Atlantis, 2006.

. Bögarnas Zarah: Diva, ikon, kult (Queer Zarah: Diva, Icon, Cult). Stockholm: Normal Förlag, 2009.

Ilska, hopp och solidaritet. Med feministisk scenkonst in $i$ framtiden (Anger, Hope, and Solidarity. Carrying Feminist Performance into the Future ). Stockholm: Atlas, 20 I 2.

Roth, Nathan. "Sigmund Freud's Dislike of Music: A Piece of Epileptology." Bulletin of the New York Academy of Medicine 62 (I986): 759-765.

Sernhede, Ove, and Johan Söderman. Hip Hop in Sweden: A Voice for Marginalized Youth. New York: Peter Lang, 2012.

Sontag, Susan. "Notes on 'Camp."' In Against Interpretation, and Other Essays, 275-292. New York: Farrar, I964.

Williams, Linda. "Film Bodies: Gender, Genre, and Excess." Film Quarterly 44 (I99I): 2-I3. 